\title{
Prediction of Swelling Kinetics of Expansive Soils of Rufisque (Senegal, West Africa)
}

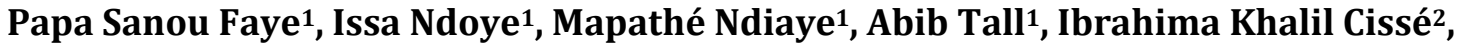 \\ Jean Pierre Magnan ${ }^{3,4}$ \\ ${ }^{1}$ Laboratoire de Mécanique et Modélisation, UFR Sciences de l’Ingénieur, Université de Thiès, Thiès, Sénégal \\ ${ }^{2}$ Laboratoire de Matériaux, Mécanique et Hydraulique, Ecole Polytechnique de Thiès, Thiès, Sénégal \\ ${ }^{3}$ Département de Géotechnique, Environnement, Risques Naturels et Sciences de la Terre (GERS), Marne-la-Vallée, France \\ ${ }^{4}$ Institut Français des Sciences et Technologies des Transports, de l'Aménagement et des Réseaux (IFSTTAR), \\ Marne-la-Vallée, France \\ Email: sanou.faye@univ-thies.sn
}

How to cite this paper: Faye, P.S., Ndoye, I., Ndiaye, M., Tall, A., Cissé, I.K. and Magnan, J.P. (2017) Prediction of Swelling Kinetics of Expansive Soils of Rufisque (Senegal, West Africa). Open Journal of Civil Engineering, 7, 267-281.

https://doi.org/10.4236/ojce.2017.72017

Received: March 15, 2017

Accepted: June 18, 2017

Published: June 21, 2017

Copyright $(9) 2017$ by authors and Scientific Research Publishing Inc. This work is licensed under the Creative Commons Attribution International License (CC BY 4.0).

http://creativecommons.org/licenses/by/4.0/

\begin{abstract}
The disorders caused by the swelling of the soil on the structures have been observed for several years in the city of Rufisque. This article presents the results of the study of swelling kinetics of expansive soils in Rufisque and their prediction based on the hyperbolic rule. The odometer is used as an instrument for measuring swelling and the tests are carried out on some intact samples at their sampling water content. The present study shows that in Rufisque the most swelling layer is marl. The results show two phases of development. The first phase is very fast and represents $77 \%$ of the final deformation and the second one is slower. The prediction of the issue by the hyperbolic rule shows that it underestimates the first phase but gives a good prediction of the second phase of the swelling rate. There is a good correlation between the final swelling rates. However, the model gives a bad approximation of the halfswelling time.
\end{abstract}

\section{Keywords}

Marls, Marls Clays, Clays, Kinetic, Swelling, Expansive Soils, Hyperbolic Rule, Rufisque

\section{Introduction}

The swelling of natural soils is specific to materials containing clayey minerals capable of interacting with water. These soils shrink and expand depending on their water content and environmental factors. These volume variations result in changes in the physical characteristics of the soil and in disturbances which are sometimes responsible for serious damage. The expansive soils are located in 
geographical areas which show large seasonal moisture deficits, where evapotranspiration superior to precipitations favors their formation. They have been described in Central Europe, Australia, Asia, the southern United States, and in African countries of the tropical belt. The damages caused by this phenomenon are estimated in the United States at $\$ 2.3$ billion in 1973 and then from $\$ 7$ billion to $\$ 9$ billion in 1986 and they exceed all natural risks [1]. In France, the amount of the compensations paid between 1990 to 2003 and 2008 was estimated at around 3.3 billion Euros, making it the second largest cause of compensation for natural disasters after floods [2]. In Senegal, the extent of damages caused by these soils to buildings in the town of Rufisque is such that more than $30 \%$ of the villas built by SIPRES have been submitted to underpinning work. Some villas have even been declared disaster-stricken because of their extremely advanced degradation status [3].

In the city of Rufisque, the disorders caused by the swelling of soils on light buildings have been observed for several years. Around the 1980s, following an expertise of the degraded buildings, it was realized that they were swelling soils. Since 1983, these expansive soils have been the subject of many researches. Authors such as [4] [5] [6] [7] confirmed the expansive nature of Rufisque soils. These works made possible to identify the real causes of the premature degradation of structures in this city and to define constructive preventive measures.

The original swelling mechanisms of soils have been widely studied, but it is still difficult to establish a relationship between the progression of the issue and the time. Indeed, the changes caused by the swelling of expansive soils are the result of a long process, involving the chemical, mineralogical proprieties and water. It often takes 5 to 10 years to see stabilized movements in the center of a building [8]. This slowness makes it sometimes difficult to follow the movement due to the swelling until stabilization. This generally leads to an underestimation of the swelling capacity of soils. For example, in Senegal, as in many countries, the swelling is considered stable after 24 hours of immersion.

The study of the kinetics of swelling arouses many interests [9] [10] [11]. It makes it possible to predict or to check the deformations induced by the swelling over time in order to take them into account in the measurement of the structures or to consider a better stabilization technique. However, while it is easy to identify the swelling phenomenon, its quantification as function of the time remains delicate because of its long-term behavior, where the importance of establishing a model to simulate the activity of the clays and to predict this phenomenon endlessly.

The objective of this article is to study the swelling kinetics of the expansive soils of Rufisque and to predict their behavior based on the hyperbolic rule.

\section{Characterization of the Study Area}

The sedimentary province of Rufisque is located at about $25 \mathrm{~km}$ south-east of the peninsula of Dakar, in the immediate vicinity of the Atlantic Ocean. It lies between the meridians $17^{\circ} 15^{\prime} \mathrm{W}$ and $17^{\circ} 20^{\prime} \mathrm{W}$ and the parallels $14^{\circ} 41^{\prime} 00^{\prime \prime} \mathrm{N}$ and 
$14^{\circ} 46^{\prime} 30^{\prime \prime} \mathrm{N}$, at the western extremity of the large Senegalo-Mauritanian MesoCenozoic sedimentary basin [12]. It is bounded to the east by the department of Pikine, to the south by the Atlantic Ocean and to the east by the municipality of Bargny and extends over an area of $550 \mathrm{~km}^{2}$. In this zone, the climate tropical and characterized by the alternation of a dry season, that lasts nine (9) months, and a rainy season that lasts three (3) months. The annual rainfall average from 1921 to 2004 is $500 \mathrm{~mm}$ at the Rufisque station. The monthly maximum temperatures average can reach $30.9^{\circ} \mathrm{C}$ in October and the minimum exceed $17^{\circ} \mathrm{C}$ in February.

The geology of Rufisque belongs to that of the peninsula of Cape Verde which is in the western extremity of the Senegalo-Mauritanian basin. The structure of the Senegal-Mauritanian basin is complicated in western Senegal by some brittle tectonics marked by the appearance of a network of faults. Those breaks, whose main system is oriented from N-S to NE-SW, delimited rising blocks such as the Ndiass and Dakar horsts and collapsed blocks like the Rufisque graben. The different outcrops encountered in the area of Rufisque-Bargny are formed by a volcanic group and a sedimentary group of tertiary to quaternary age.

- The entire sedimentary to which is dated the inferior Eocene (Ypresien) to the medium (Lutetien), includes the Member of Cap des Biches and the Member of Rufisque [13]. The Cap des Biches Member is composed of a reciprocation of some grey yellowish micritic limestones and some multi-decimeter thickness marl layers. The rich marls in association of the planctonik and benthic foramen (Lutetien basis) enriched progressively to the top in stratified silicate horizons which affect preferentially calcareous horizons with phosphatic elements [14] [15]. The Member of Rufisque is made from three 3 meters of marno-calcareous alternation mostly marled, rich in planctonik and benthic foramen, which indicate a Lutetien age. The white foliated marls have shown the presence of calcareous layer in a very abundant phosphatic and discocycline shovelful [13].

- The whole volcanic is composed to a big nephelinit flow set in as $20.9 \pm 0.6$ et $13.5 \pm 0.2 \mathrm{Ma}[16]$ in Diokoul and a whole basanitic dykes and sills in Cap des Biches set in as $23.74 \pm 0.50 \mathrm{Ma}$ [17] such breach associated to the rift network NS which cut up the sedimentary sequence. In Cap des Biches, many pricking volcanic rocks flush along the coast at low tide between coordinates (N14.71399 - W17.28947 et N14.72530 - W17.31603). It represents mainly the dykes extended by the sills trespassing in the sedimentary sequence. Locally, it can be seen many angular fragments of sedimentary rocks, which can be superior to the $\mathrm{m}^{3}$, intimately associated to the lava, and probably resulting from phreato-magmatic eruption.

- The flushing quaternaries are composed by beach rocks, azoïque sand deposits or rich littoral fauna [14].

\section{Geotechnical Characterization of Materials}

The studied soils are taken from two sites in Rufisque: Cap des Biches and Arafat. The map below (Figure 1) gives the precise location of the sites and the position 
of the surveys carried out. In each sampling, intact samples and remodeled samples are taken from the homogeneous parts of the swellable layers. The remodeled samples will be used for geotechnical identification testing and intact sampling to the extent of natural water content and swelling. The geotechnical characteristics of the soils taken from the two sites are presented in Table 1 and Table 2.

Analysis of the sampling profiles carried out in this sector reveals a great heterogeneity with a strong presence of soils susceptible to swelling (Figure 1). In

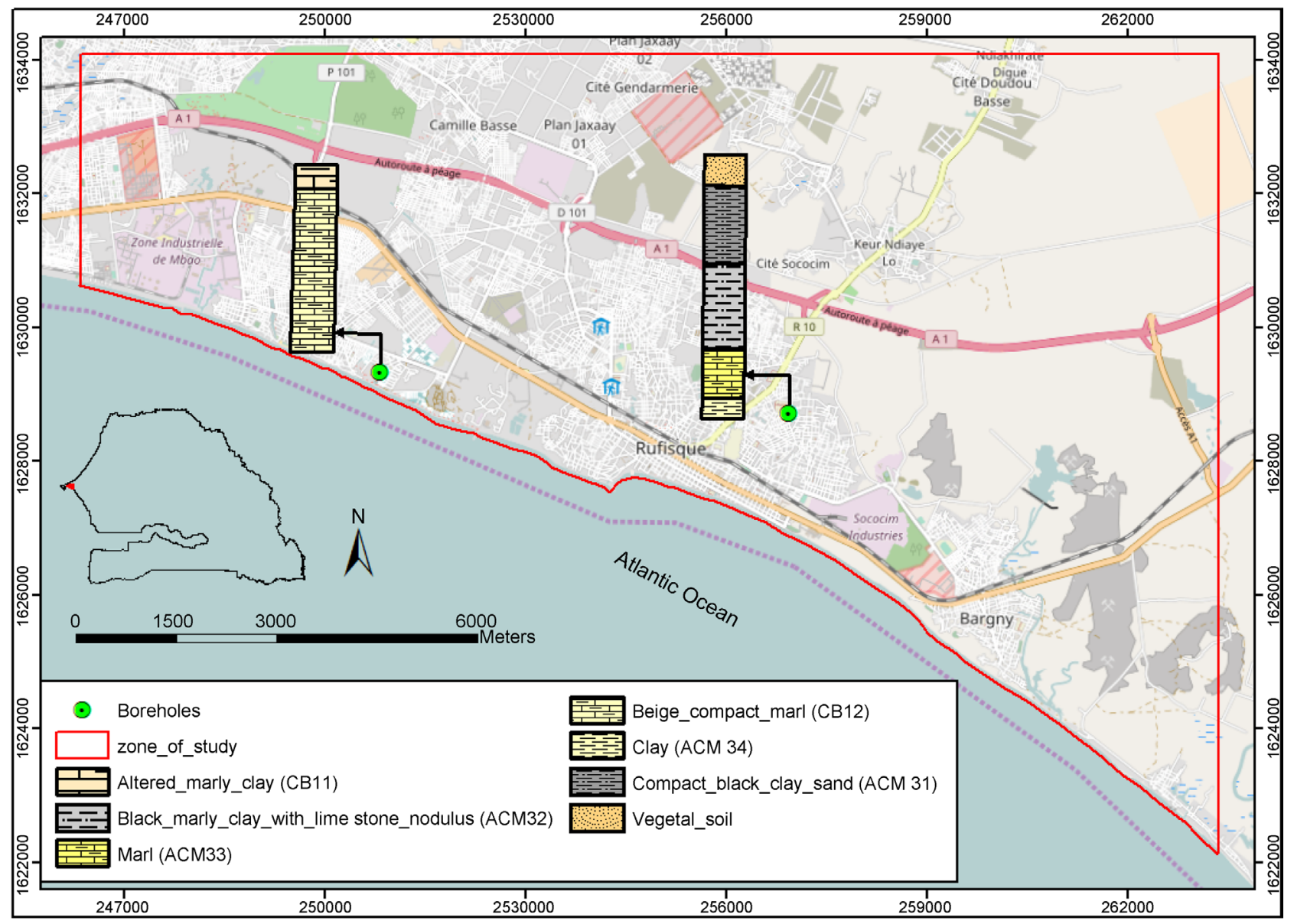

Figure 1. Location of boreholes sites and positions.

Table 1. Geotechnical characteristics of Arafat soils.

\begin{tabular}{|c|c|c|c|c|c|c|c|c|c|c|c|c|}
\hline Site & Ech. & $\operatorname{Depth}(\mathrm{m})$ & $\mathrm{W}_{\mathrm{n}}(\%)$ & $\gamma\left(\mathrm{kN} / \mathrm{m}^{2}\right)$ & $\gamma_{\mathrm{d}}\left(\mathrm{kN} / \mathrm{m}^{2}\right)$ & $\gamma_{\text {sat }}\left(\mathrm{kN} / \mathrm{m}^{2}\right)$ & $\gamma_{\mathrm{s}}\left(\mathrm{kN} / \mathrm{m}^{2}\right)$ & $\mathrm{W}_{\mathrm{L}}(\%)$ & PI (\%) & VB & $\%<2 \mu \mathrm{m}$ & $A_{c}$ \\
\hline \multirow{4}{*}{ Arafat } & ACM31 & 0.44 à 1.36 & 11 & 17.7 & 15.9 & 20.0 & 27 & 44 & 31 & 6.5 & 15 & 0.43 \\
\hline & ACM32 & 1.36 à 2.20 & 14 & 16.9 & 15.1 & 19.5 & 26.9 & 52 & 33 & 7.1 & 24 & 0.30 \\
\hline & ACM33 & 2.20 à 2.60 & 37 & 16.0 & 11.8 & 17.5 & 27.1 & 158 & 115 & 10.6 & 32 & 0.33 \\
\hline & ACM34 & 2.60 à 3.00 & 46 & 14.2 & 9.8 & 16.0 & 26.1 & 158 & 86 & 13.4 & 25 & 0.54 \\
\hline
\end{tabular}

Table 2. Geotechnical characteristics of cap des Biches soils.

\begin{tabular}{|c|c|c|c|c|c|c|c|c|c|c|c|c|}
\hline Site & Ech. & $\operatorname{Depth}(\mathrm{m})$ & $\mathrm{W}_{\mathrm{n}}(\%)$ & $\gamma\left(\mathrm{kN} / \mathrm{m}^{2}\right)$ & $\gamma_{\mathrm{d}}\left(\mathrm{kN} / \mathrm{m}^{2}\right)$ & $\gamma_{\text {sat }}\left(\mathrm{kN} / \mathrm{m}^{2}\right)$ & $\gamma_{\mathrm{s}}\left(\mathrm{kN} / \mathrm{m}^{2}\right)$ & $\mathrm{W}_{\mathrm{L}}(\%)$ & PI (\%) & VB & $\%<2 \mu \mathrm{m}$ & $A_{c}$ \\
\hline \multirow{2}{*}{ Cap des Biches } & $\mathrm{CB} 11$ & 0 à 0.27 & 22 & 17.7 & 14.3 & 19.1 & 27 & 153 & 98 & 4.5 & 44 & 0.10 \\
\hline & CB12 & 0.27 à 2.00 & 12 & 17.4 & 14.9 & 19.5 & 27.2 & 139 & 87 & 2.9 & 34 & 0.09 \\
\hline
\end{tabular}


Arafat; there is a succession of clayey sands to very clayey in depth, followed by marl clay then marl that rests on a clay, whereas at Cap des Biches, it is made up of marl clay on the surface and becomes very compact to calcareous in depth. Figure 2 shows the particle size distribution of the studied soils. Marl and marl clays are highly plastic and clay sands and clays are poorly plastics (Figure 3). According to the [18] and [19] classification, the studied soils are swelling with degrees of expansion ranging from medium to very large.

\section{Methodology}

\subsection{Measurement of Swelling Kinetics}

In this work, the odometer is used as an instrument for measuring the swelling kinetics. The swelling tests were carried out on intact samples at their sampling water content. Cylindrical specimens were made while avoiding to disturb them. The samples were placed in greased odometrer cells to reduce the effect of lateral friction. The test samples are then immersed in distilled water, allowed to swell freely under a small normal stress. The movement is read at increasing steps of time during the first hours, then every 24 hours until the total stabilization of the swelling. The latter is considered stable when no movement is recorded during 6 consecutive readings days. The swelling potential $(\varepsilon)$ is given by the following relation:

$$
\varepsilon(\%)=\frac{\Delta H}{H} \times 100
$$

with: $\Delta H$ the vertical displacement and $H$ the initial height of the sample.

\subsection{Description of the Hyperbolic Rule}

Experimentally, swelling kinetics, as a general rule, can be approximated by a

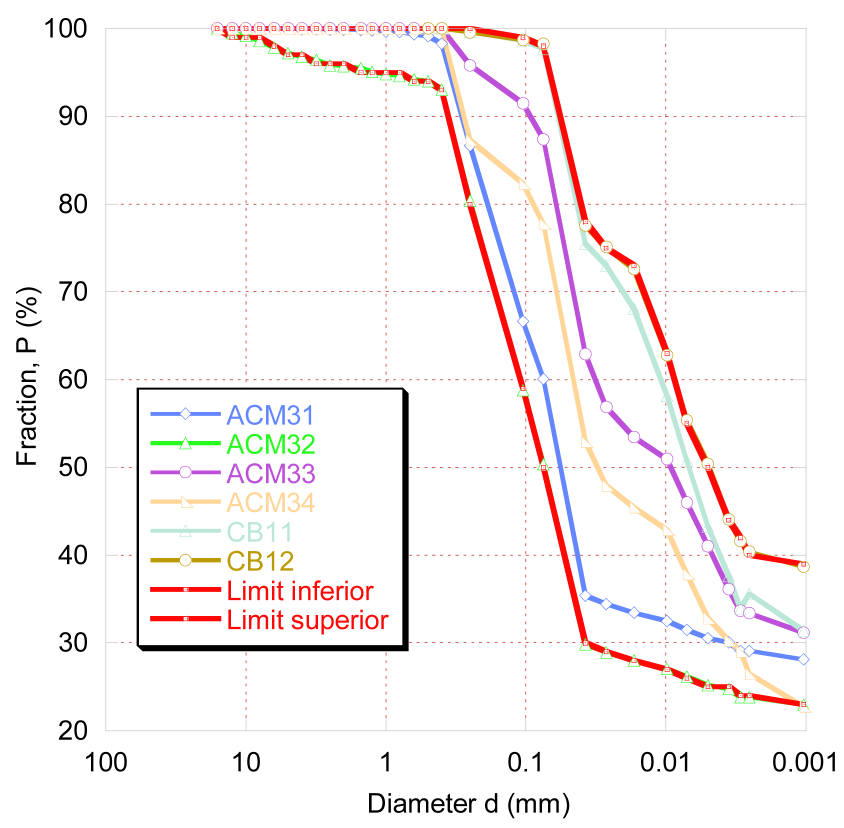

Figure 2. Granulometry of Arafat and cap des Biches soils. 


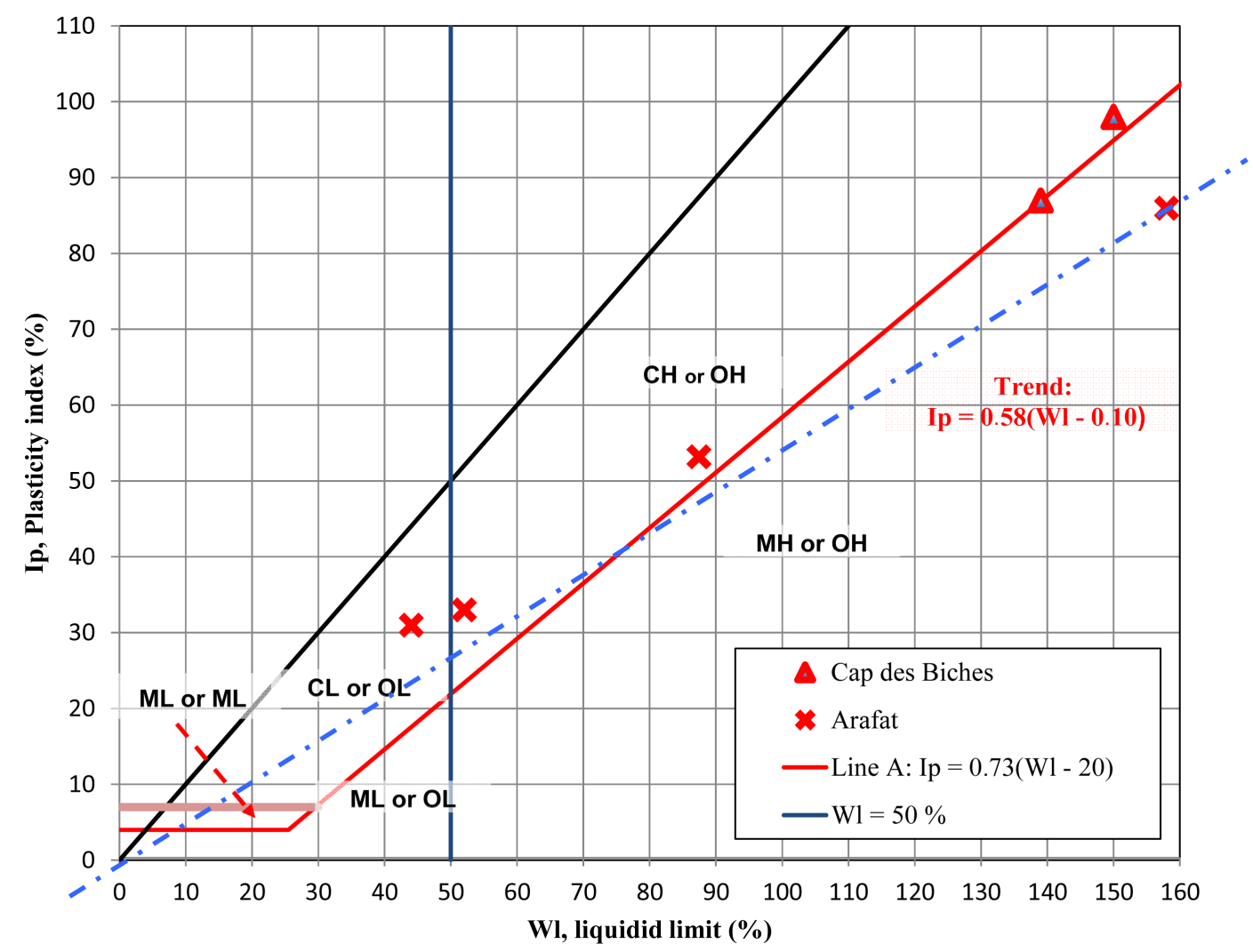

Figure 3. Classification of soils Arafat and cap des Biches.

hyperbolic relation [10] [20] [21] [22] [23]. The evolution of soil swelling as function of time can be predicted by a rectangular hyperbolic relation [10].

$$
\varepsilon=\frac{t}{\beta t+\alpha}
$$

with $t$. time elapsed, $\beta$ and $\alpha$ : constants determined graphically and correspond respectively to the slope of the line $\left(t, \frac{t}{\varepsilon}\right)$ and $\alpha$ the intercept.

The validity of the model can be demonstrated if the curve of the inverse of the swelling speed $\left(\frac{t}{\varepsilon}\right)$ as function of time $(t)$ is a straight line. Thus, the linear relation which is of the form (3).

$$
\frac{t}{\varepsilon}=\beta t+\alpha
$$

The hyperbolic relation also predicts the maximum value of the swelling at an infinite time. The maximum swelling is always equal to $\left(\frac{1}{\beta}\right)$, which corresponds to the inverse of the slope of the regression line of the experimental points expressed in the diagram $\left(t, \frac{t}{\varepsilon}\right)$.

$$
\operatorname{Lim}_{t \rightarrow \infty} \varepsilon=\frac{1}{\beta}
$$


Vayssade (1978) proposes a hyperbolic rule of the following form:

$$
\varepsilon=\varepsilon_{\text {inf }} \frac{t}{t_{0.5}+t}
$$

$\mathcal{E}_{\text {inf }}$ represents the final swelling rate obtained for an infinite time and $t_{0.5}$ the half-swelling time (relative to the final swelling). This model can be written as an equation of a straight line in the coordinate $\operatorname{system}\left(t, \frac{t}{\varepsilon}\right)$ where $\varepsilon$ and $t_{0.5}$ can be determined graphically.

$$
\frac{t}{\varepsilon}=\frac{1}{\varepsilon_{\mathrm{inf}}} t+\frac{t_{0.5}}{\varepsilon_{\mathrm{inf}}}
$$

The numerical simulation of the hyperbolic rule was performed with the Matlab R2013 software. The results of the numerical simulation were compared to the experimental data.

\section{Results and Interpretation}

The experimental results of the swelling kinetics of the expansive soils of Arafat and Cap des Biches are shown in Figure 4 and Figure 5.

In order to evaluate the validity of the hyperbolic rule on the swelling soils of Rufisque, Figure 6 and Figure 7 show the inverse of the swelling rate $\left(\frac{t}{\varepsilon}\right)$ according to time $(t)$ and then the parameters of the model can be deduced.

Analysis of the swelling layer by layer shows that the amplitude of swelling according to depth increases at Arafat while it decreases at Cap des Biches. In Arafat, the most swelling layer is between 2.20 and $2.60 \mathrm{~m}$ with swelling amplitude of $0.94 \mathrm{~mm}$ whereas at Cap des Biches, the surface layer is the most swelling

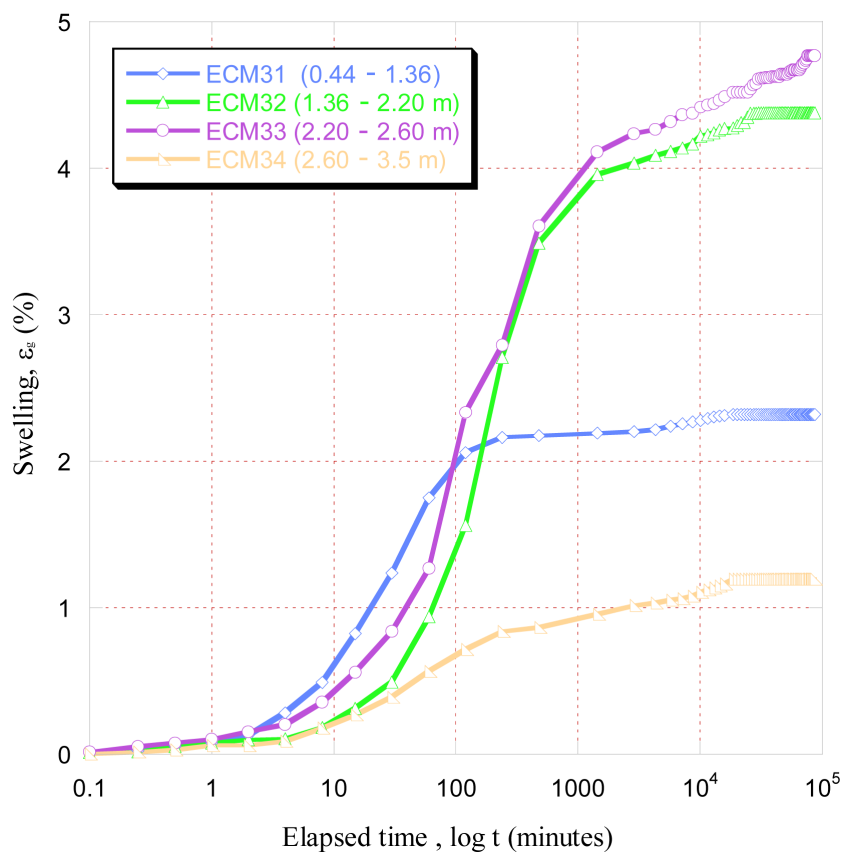

Figure 4. Arafat soil swelling kinetics. 


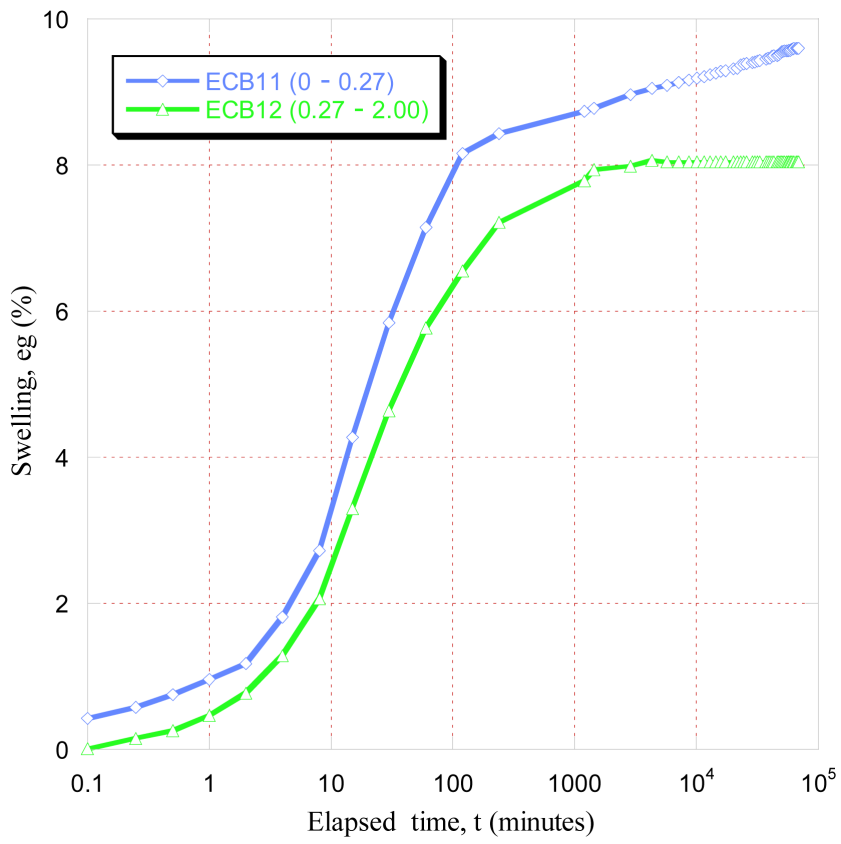

Figure 5. Cap des Biches soil swelling kinetics.

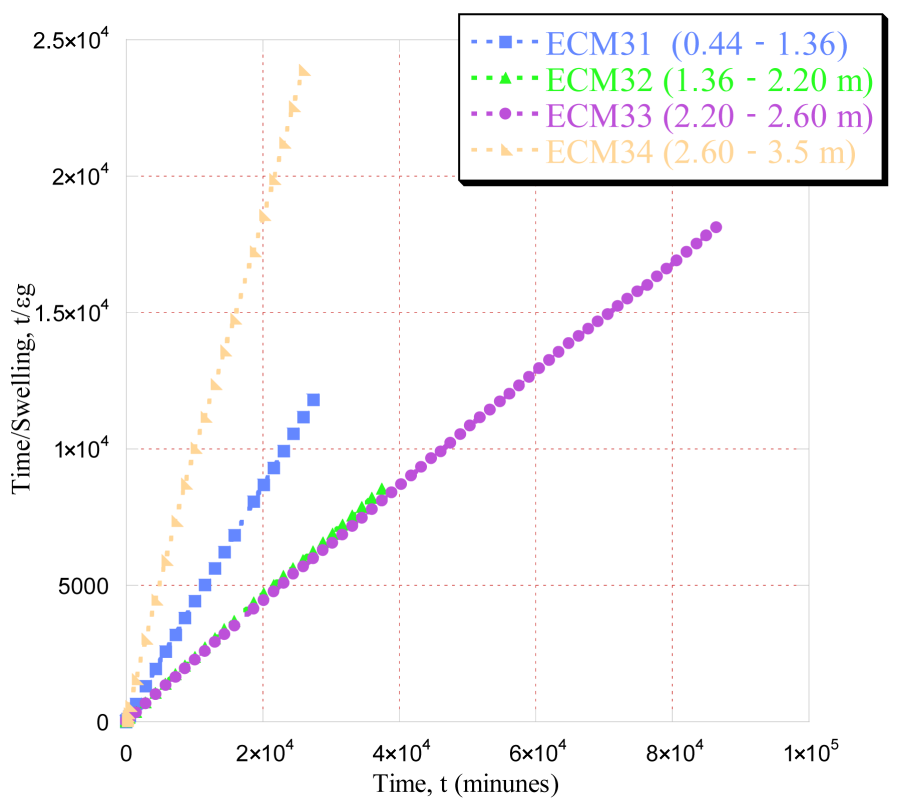

Figure 6. Determination of model parameters for Arafat soils.

with amplitude of swelling of $1.80 \mathrm{~mm}$. For both sites, the swelling is relatively slow and may exceed 30 days.

The study of the swelling kinetics of the expansive soils of Arafat and Cap des Biches highlights two phases; primary swelling and secondary swelling. The primary swelling takes place in less than 48 hours and represents more than $77 \%$ of the final swelling. For Rufisque soils, swell speeds reached 0.0034 to 0.013 $\mathrm{mm} \cdot \mathrm{min}^{-1}$ for samples from Arafat and 0.084 to $0.116 \mathrm{~mm} \cdot \mathrm{min}^{-1}$ for samples from Cap des Biches at the end of the primary phase. The primary swelling is carried out in two stages. The first step would correspond to the filling of the intervals of 


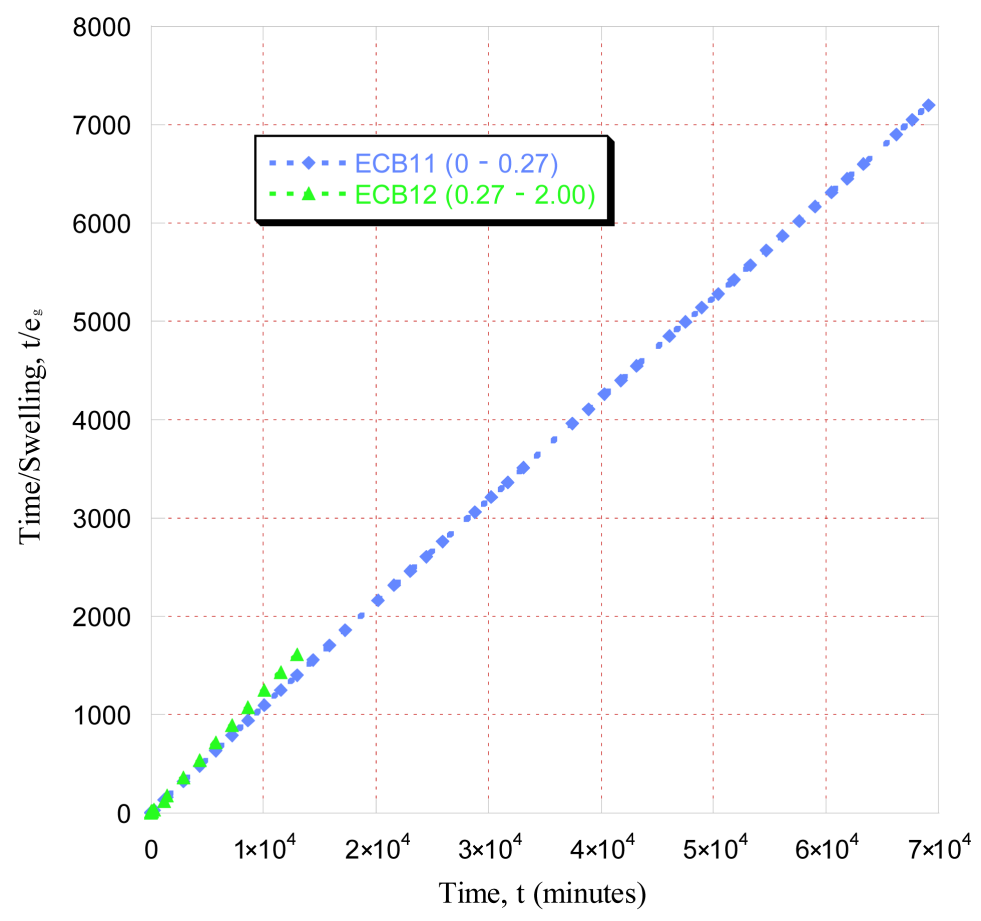

Figure 7. Determination of model parameters for Cap des Biches soils.

the non-swelling fraction. It does not reflect a real swelling of the material, but an overall contraction due to the penetration of water into the pores, it depends on the void index and the swelling and non-swelling fraction of the material [10] [20] [24] [25]. The second stage corresponds to the primary swelling itself. It reflects the end of the dissipation of the suction. It is fast at first and gradually decreases to an asymptote.

The secondary swelling was slower with velocities ranging from $1.068 \times 10^{-5}$ to $2.78 \times 10^{-5} \mathrm{~mm} \cdot \mathrm{min}^{-1}$ for the Arafat samples and from $1.2 \times 10^{-4}$ to $2.84 \times 10^{-5}$ $\mathrm{mm} \cdot \mathrm{min}^{-1}$ for the Cap des Biches samples. This phase is related to the percentage of clayey minerals and their nature. It reveals the hydration of clayey minerals and the beginning of the physicochemical properties of expansive soils [26] [27].

The comparison of the experimental curves with the curves predicted by the model shows a good agreement of the appearances. The predicted curves (Figures 8-13) make it possible to account for the different phases of the swelling kinetics. However, there is an offset between the two curves which is all the more important as the sample is swelling. The estimation of the relative deviation between the experimental measurements and the predicted measurements shows that the hyperbolic law underestimates the first phase of swelling kinetics. This underestimate is maximal at the beginning of swelling with $94 \%$ error for Arafat samples and $99 \%$ for Cap des Biches samples. This is due to the fact that the first variations in volume do not really correspond to the swelling of the sample but to a filling of the voids in the material. There is a good correspondence between the two curves from the second phase of the swelling. The model provides a good approximation of the final swelling rate with deviations of less than 1.5\%. Figure 14 shows that there is a perfect correlation between the observed and 


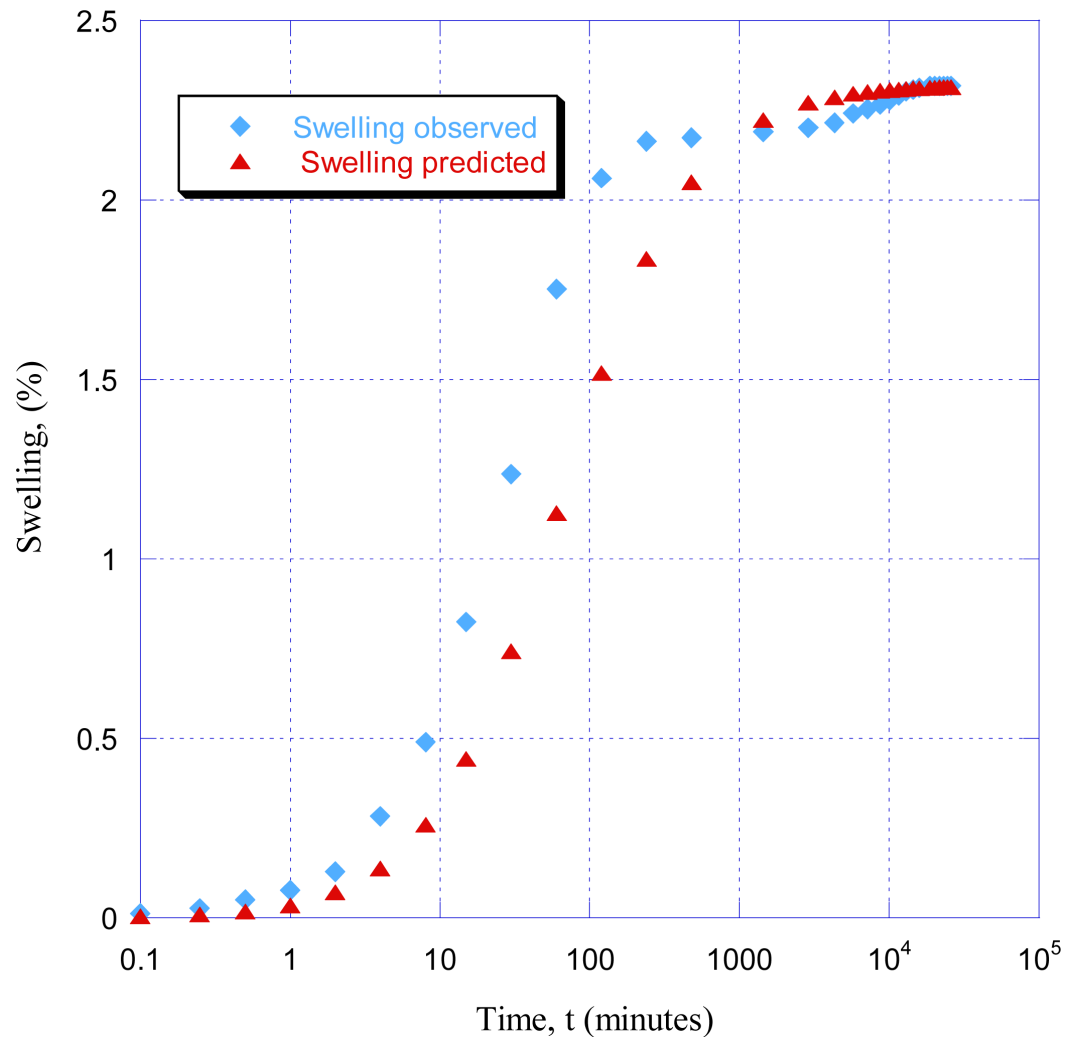

Figure 8. ACM31 swelling kinetics: comparison of the experimental results to the numerical simulation.

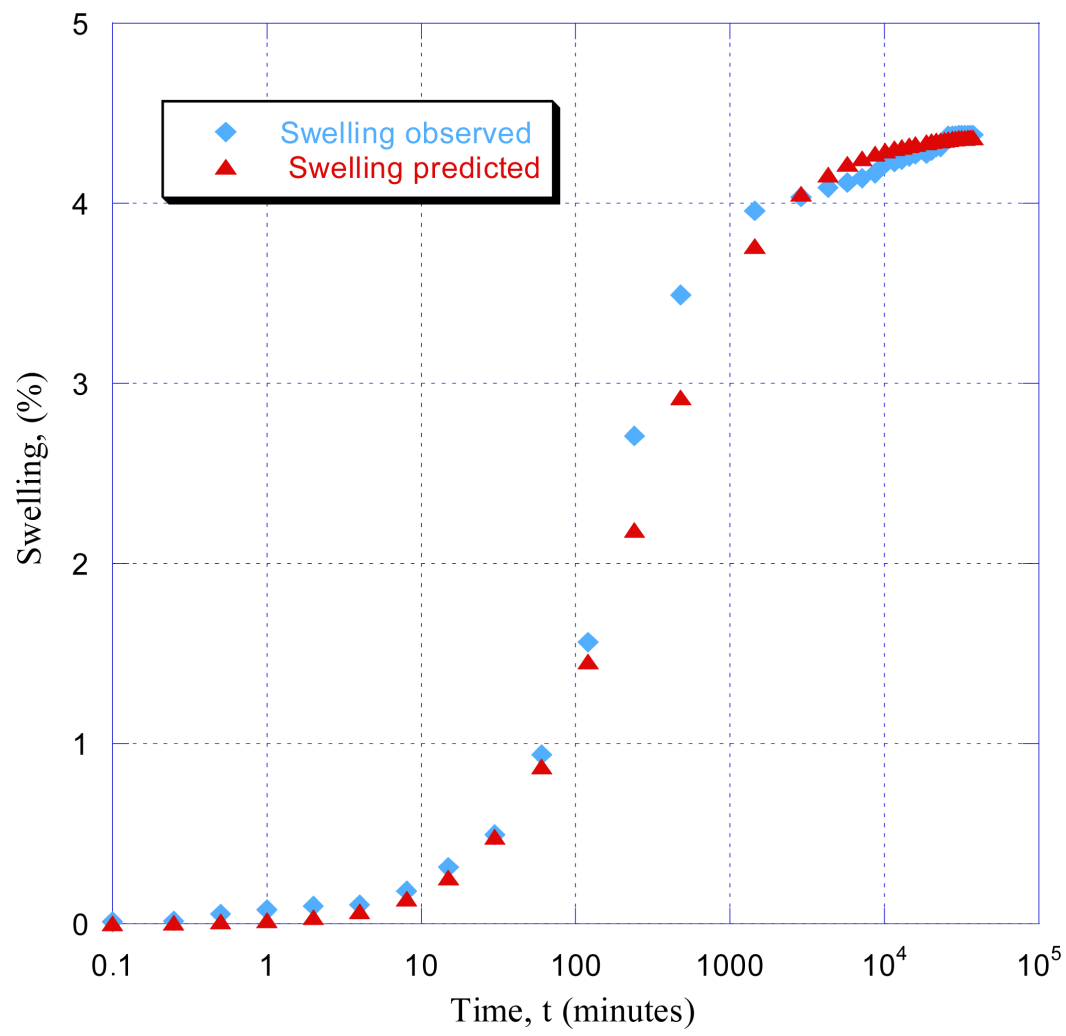

Figure 9. ACM32 swelling kinetics: comparison of the experimental results to the numerical simulation. 


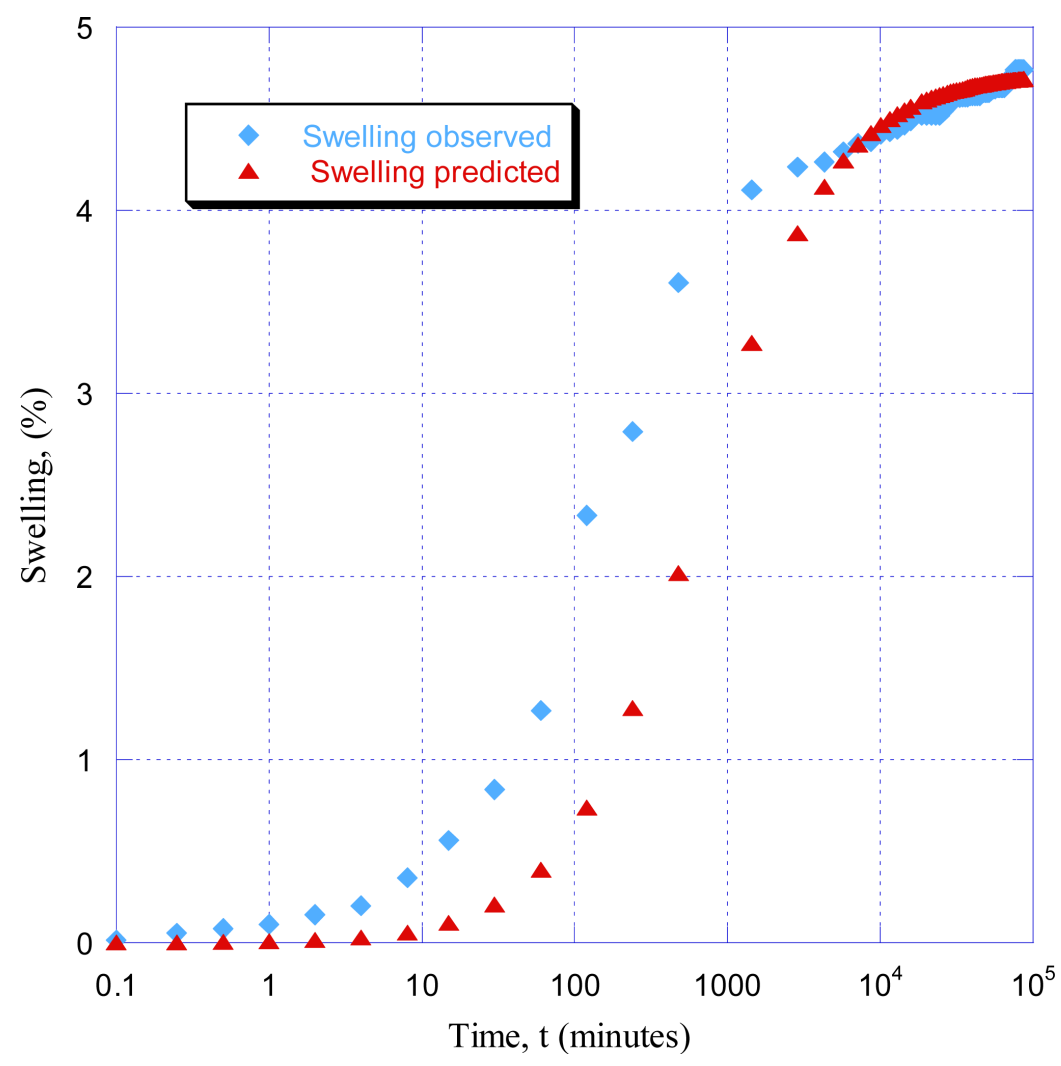

Figure 10. ACM33 swelling kinetics: comparison of the experimental results to the numerical simulation.

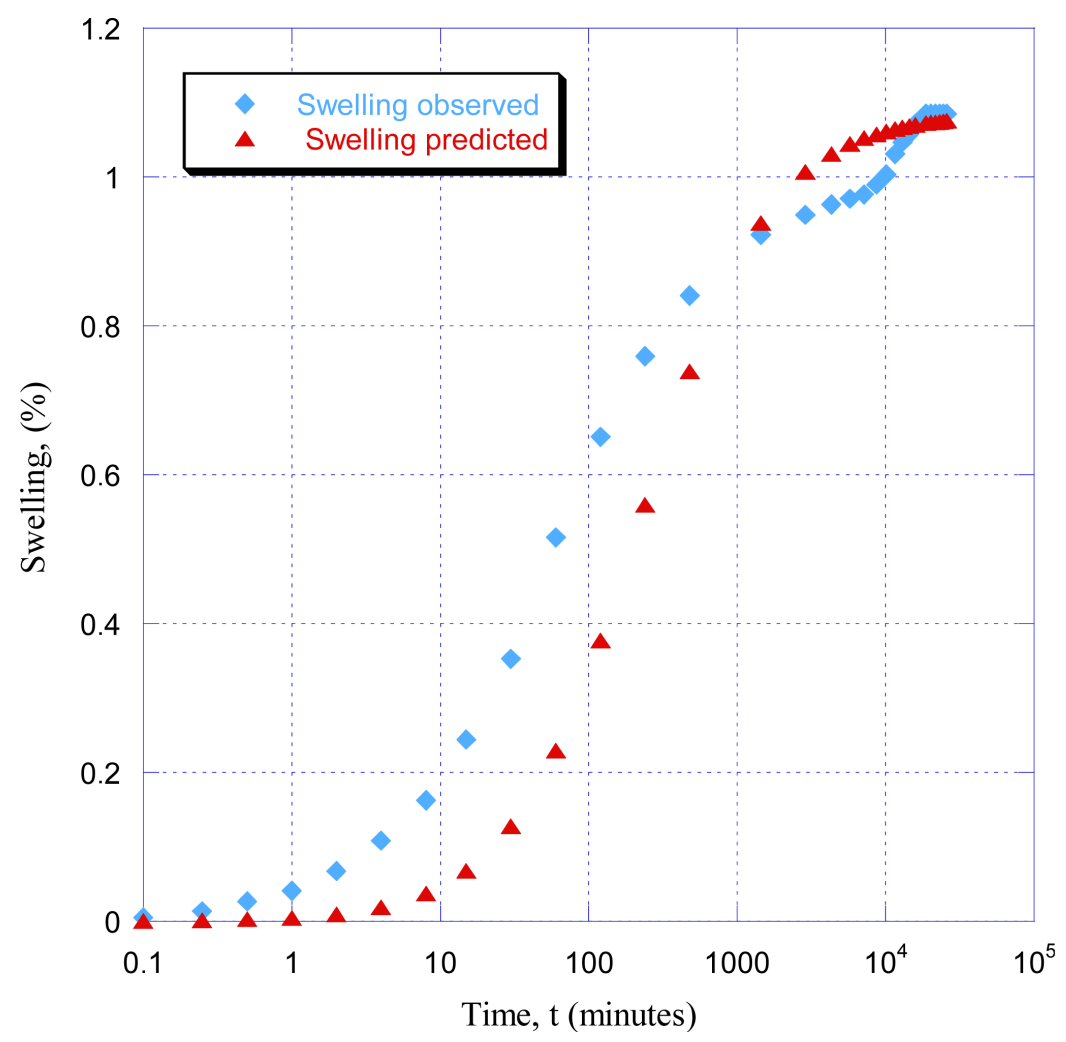

Figure 11. ACM34 swelling kinetics: comparison of the experimental results to the numerical simulation. 


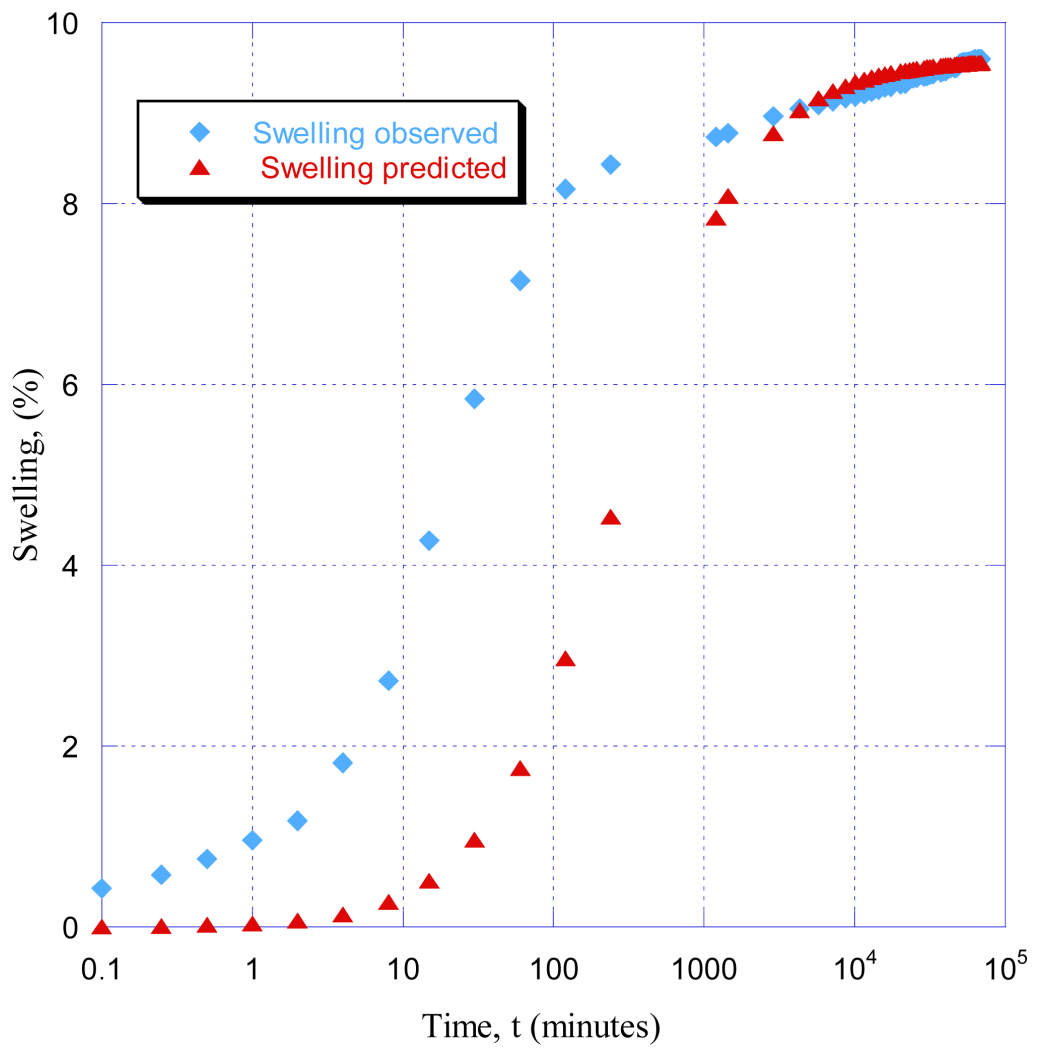

Figure 12. CB11 swelling kinetics: comparison of the experimental results to the numerical simulation.

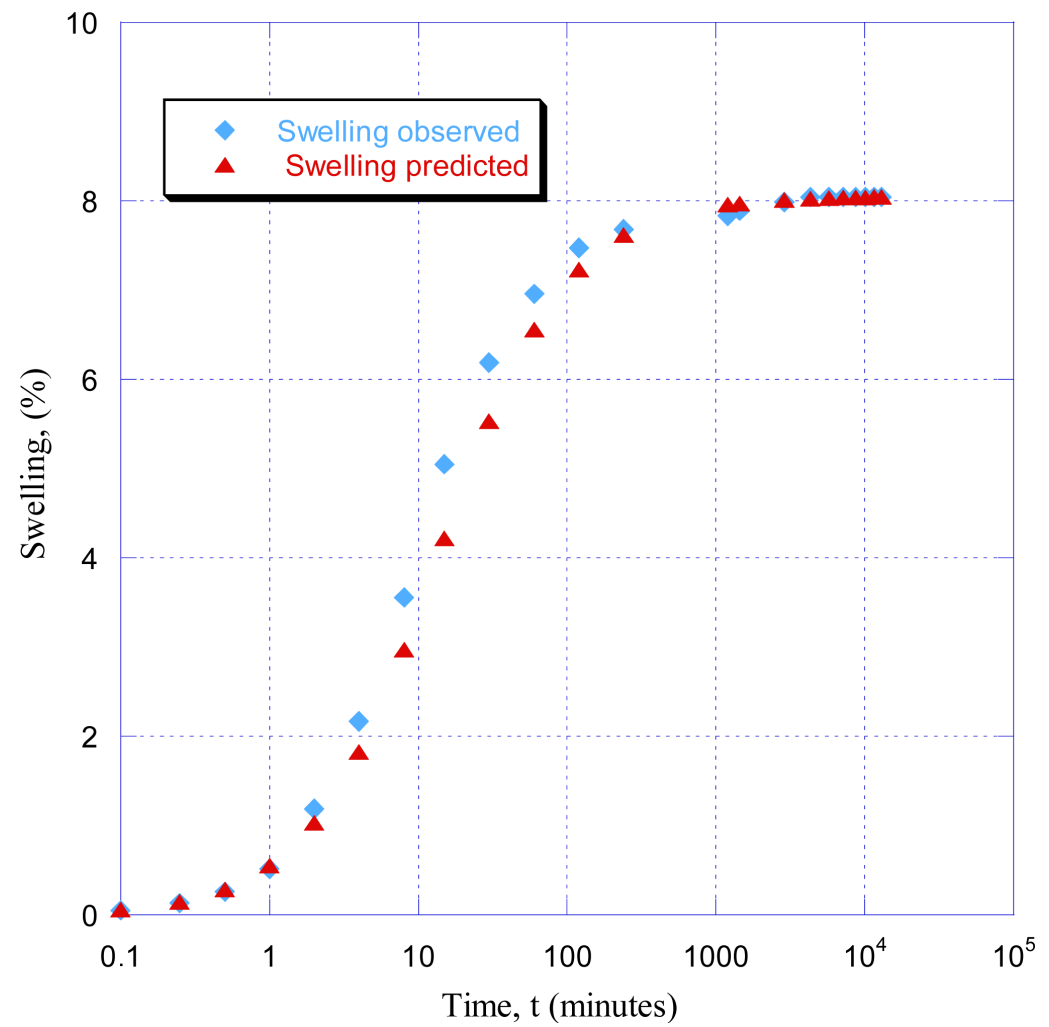

Figure 13. CB12 swelling kinetics: comparison of the experimental results to the numerical simulation. 


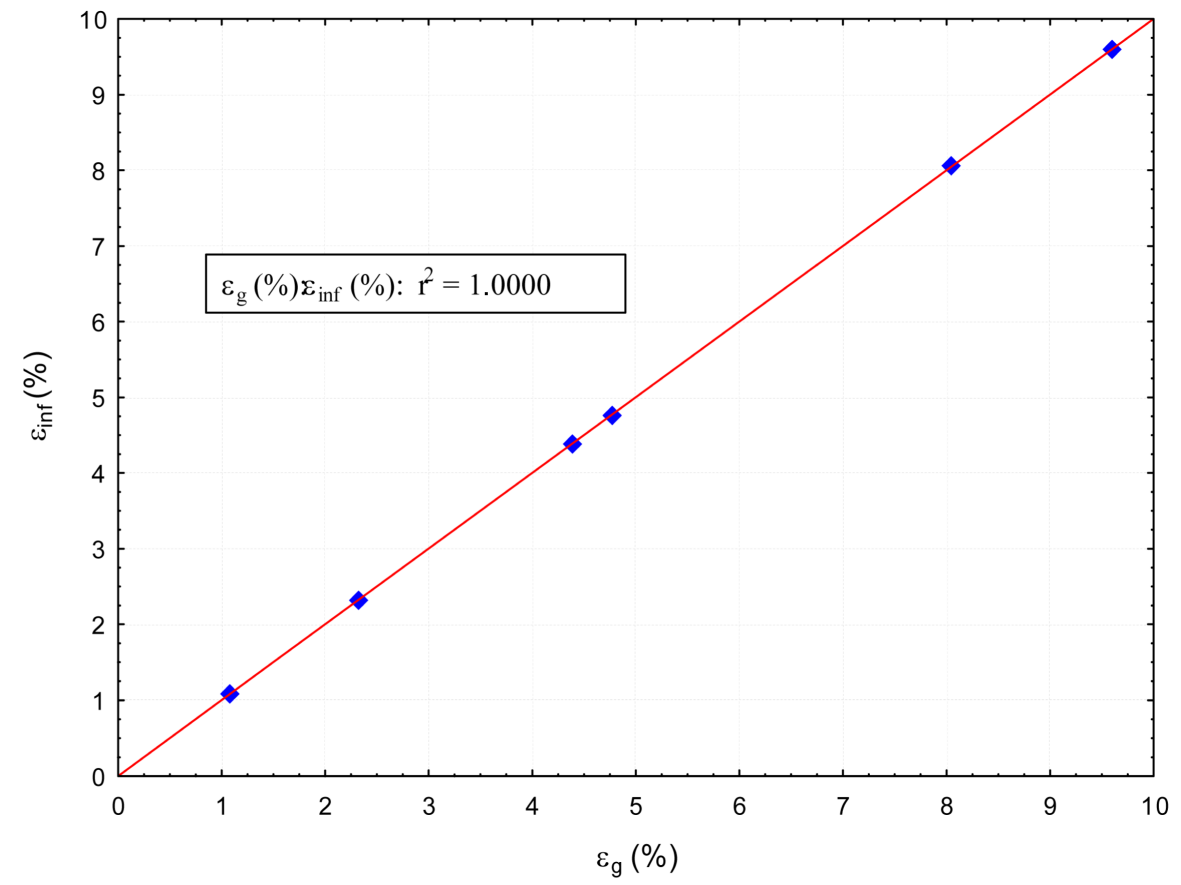

Figure 14. Correlation between the final swelling rate observed $\left(\varepsilon_{g}\right)$ and predicted $\left(\varepsilon_{\text {inf }}\right)$.

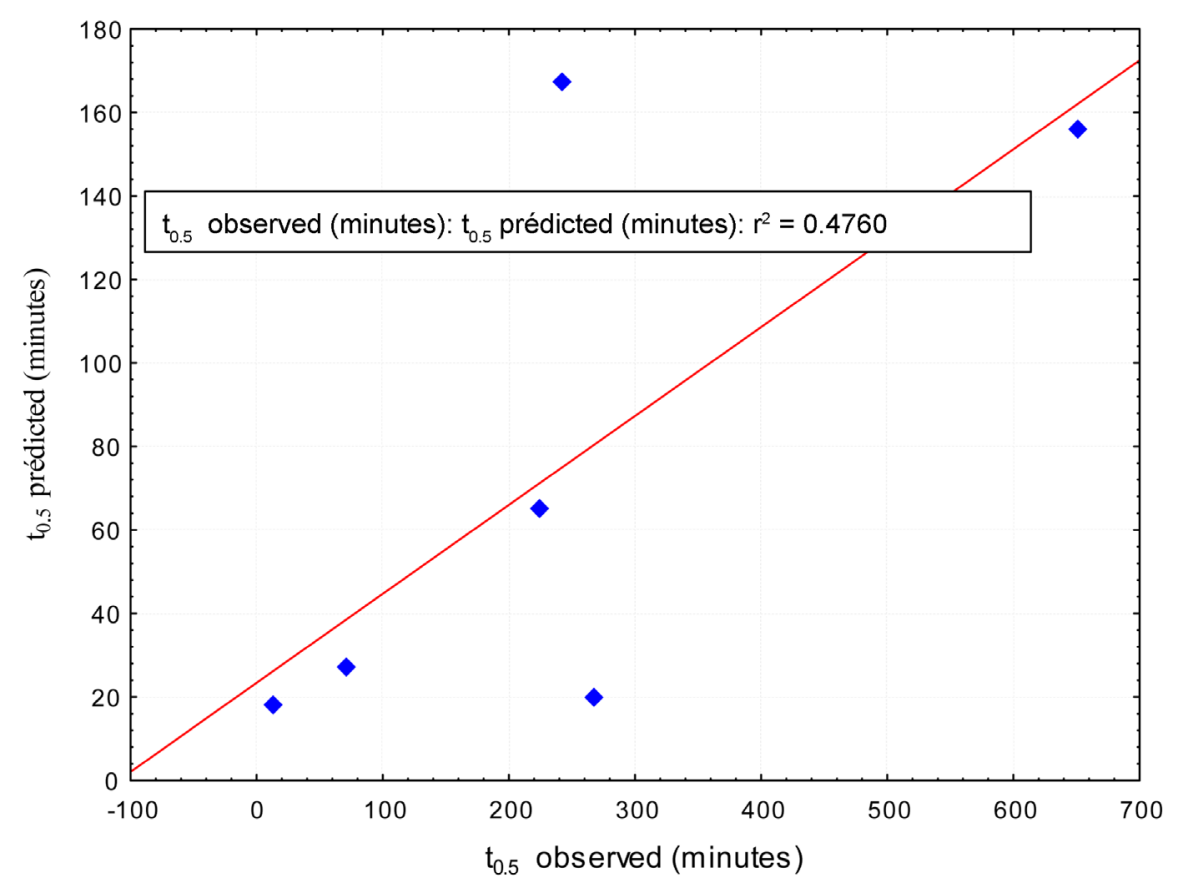

Figure 15. Correlation between the observed and predicted half-swelling time.

predicted final swelling rate. However, this correlation is almost absent between the observed and predicted half-swelling time (Figure 15). This poor prediction results from the stronger influence of the first phase of the primary swelling.

\section{Conclusion}

This article highlighted the swelling of the soils of Rufisque according to time. 
This study shows that swelling is a very slow multi-phase process that can last several weeks before its stabilization. In this area, the behavior of soils differs from one sector to another. The shape of the kinetic curves of the soils of Rufisque corroborates that obtained in the literature. Its prediction based on the hyperbolic rule reveals that the model underestimates the kinetics of the primary swelling as well as the half-swelling time. However, it gives a good approximation of the final swelling rate. Yet, for a more reliable representation of the swelling kinetics of the expansive soils of Rufisque, it will be necessary to consider an improvement of the model by integrating the primary phase characterized by mechanical activities.

\section{Acknowledgements}

Our special and sincere thanks to the Director of SIPRES for his technical and financial support.

\section{References}

[1] Aissa Mamoune, S.M. (2002) Contribution à la mesure, prévision et modélisation du comportement des sols expansifs. Thèse Magister, Université Aboubakr Belkaid, Tlemcen.

[2] Chrétien, M. (2010) Compréhension des mécanismes de retrait-gonflement des sols argileux: Approche sur site expérimental et analyse de sinistres sur constructions individuelles. Thése, Université Bordeaux 1, 315.

[3] Diop, A. (2004) Contribution a la conception de fondations sur les sols gonflants, application au sols de la sipres cap des biches. Projet de fin détudes en vue de l'optention du diplôme d'ingénieur de conception, Ecole Polytechnique de Thies, 75.

[4] Cissé, I. (1985) Caractérisation et méthodes de construction sur sols gonflants. Application aux marnes de Rufisque (Sénégal). Thèse Doctorat Géologie de I’Ingénieur, INPL de Lorraine, 214.

[5] Thureau, J.M. (1985) Contribution à l'étude géotechnique des sols gonflants problèmes rencontrés au Sénégal.Thèse doctorat Ingénieur, Université de Nantes, 212.

[6] Cissé, I.K., Fall, M. and Rahal, A. (1999) Un cas d'instabilité de sol de fondation: Exemple des marnes gonflantes de Rufisque (Sénégal). Geotechnics for Developping Africa, Wardle, Blight \& Fourie (Eds.), Rotterdam.

[7] Fall, M., Ndiaye, M. and Niang, I. (2016) Geological and Geotechnical Characterisation of Residual Swelling Soils of Rufisque (Senegal, West Africa). Journal of Earth Sciences and Geotechnical Engineering, 6, 29-47.

[8] Mouroux, P., Margron, P. and Pinte, J.C. (1988) La construction économique sur sols gonflants. Manuels et Méthodes, 14.

[9] Seed, H.B., Woodward, R.J. and Lundgren, R. (1962) Prediction of Swelling Potential for Compacted Clays. Journal of the Soil Mechanics and Foundations Division, 88, 107-131.

[10] Dakshanmurthy, V. (1978) A New Method to Predict Swelling Using Hyperbolic Equation. Geotechnical Engineering, 9, 29-38.

[11] Komine, H. and Ogata, N. (1994) Experimental Study on Swelling Characteristics of Compacted Bentonite. Canadian Geotechnical Journal, 31, 478-490. 
https://doi.org/10.1139/t94-057

[12] Bellion, Y. (1987) Histoire géodynamique post-paléozoique de l'Afrique de l'Ouest d'après l'étude de quelques bassins sédimentaires (Sénégal, Taoudenni, Iullemmeden, Tchad). These, Universitéd' Avignon, 302.

[13] Roger, J., Banton, O., Barusseau, J.P., Castaigne, P., Comte, J.-C., Duvail, C., Nehlig, P., Noël, B.J., Serrano, O. and Travi, Y. (2009d) Notice explicative de la cartographie multi-couches à $1 / 50000$ et $1 / 20000$ de la zone d'activité du Cap-Vert. Ministère des Mines, de l'Industrie et des PME, Direction des Mines et de la Géologie, Dakar, $245 \mathrm{p}$.

[14] Brancart, R.Y. (1977) Etude micropaléontologique et stratigraphique du Paléogène sur le flanc occidental du horst de Ndiass et dans la région de Taïba. Thèse $3^{\mathrm{e}} \mathrm{cycle}$, Université Provence, Vol. 2, 89.

[15] Elouard, P., Brancart, R. and Hébrard, L. (1976) Cartes géologiques à 1/20 000 et Notices explicatives des cartes de Bargny et Rufisque (Presqu'île du Cap-Vert). Ministère du développement industriel et de l'environnement, Direction des Mines et de la Géologie, République du Sénégal, 43 et 35.

[16] Cantagrel, J.M. (1976) Nouvelles données géochronologiques sur le volcanisme ouest-africain. $4^{\mathrm{e}}$ Réun. Ann. Sci. Terre, Paris, 93.

[17] Guillo, H. (2008) Datation par la méthode potassium-argon sans traceur de roches volcaniques du Sénégal. Rapport Volcanisme LSCE 10_08, 15.

[18] Dakshanamurthy, V. and Raman, V. (1973) A Simple Method of Identifying an Expansive Soil, Soils and Foundations. Japanese Society of Soil Mechanics and Foundation Engineering, 13, 97-104. https://doi.org/10.3208/sandf1972.13.97

[19] Williams, A.B. and Donaldson, G.W. (1980) Developments Relating to Building on Expansive Soils in South Africa. 4th Conference on Expansive Soils, Denver, Vol. 2, 834-844.

[20] Vayssade, B. (1978) Contribution à l'étude du gonflement interparticulaire des sols argileux. Thèse de Doctorat, Ecole Nationale Supérieure des Mines de Paris.

[21] Sridharan, A., Sreepad Rao, A. and Sivapullaich, P.V. (1986) Swelling Pressure of Clays. Geotechnical Testing Journal, 9, 24-33. https://doi.org/10.1520/GTJ10608J

[22] Parcevaux, P. (1980) Etude microscopique et macroscopique du gonflement de sols argileux. Thèse de Doctorat, Ecole Nationale Supérieure des Mines de Paris, 266.

[23] Didier, G., Bourdeau, Y. and Kastner, R. (1985) Méthodesd'étude du gonflement des marnes. 3rd French Polish Seminar on Applied Soil Mechanics, Gdansk, 11-14 September 1985, Vol. 1, 251-264.

[24] Sivapullaiach, P.V., Sridharan, A. and Stalin, V.K. (1996) Swelling Behavior of SoilBentonite Mixtures. Canadian Geotechnical Journal, 33, 808-814. https://doi.org/10.1139/t96-106-326

[25] Al-Mukhtar, M., Touray, J.C. and Bergaya, F. (1999) Une argile modèle pour l'étude du gonflement des sols argileux: La Laponite-Na de synthèse. Compte-Rendu de I'Académie des Sciences de Paris, Sciences de la terre et des planètes, 329, 239-242.

[26] Alonso, E.E., Lloret, A., Gens, A. and Batlle, F. (1989) A New Approach for the Prediction of Long Term Heave. 12 th ICSMFE, Rio de Janeiro, Vol. 1, 571-574.

[27] Gens, A., Alonso, E.E., Lloret, A. and Battle, F. (1993) Prediction of Long Term Swelling of Expansive Soft Rocks: A Double Structure Approach. Hard Soils and Soft Rocks, Athènes, 495-500. 
Submit or recommend next manuscript to SCIRP and we will provide best service for you:

Accepting pre-submission inquiries through Email, Facebook, LinkedIn, Twitter, etc. A wide selection of journals (inclusive of 9 subjects, more than 200 journals)

Providing 24-hour high-quality service

User-friendly online submission system

Fair and swift peer-review system

Efficient typesetting and proofreading procedure

Display of the result of downloads and visits, as well as the number of cited articles Maximum dissemination of your research work

Submit your manuscript at: http://papersubmission.scirp.org/

Or contact ojce@scirp.org 